\title{
Nanomedicine in Cancer Treatment
}

\section{Krukemeyer MG* and Wagner W}

Department of Radio-Oncology, Paracelsus-Hospital, Sedanstr. 109 D-49076 Osnabrück, Germany

\section{Introduction}

More than half of the populations over 65 years old suffer from a cancer disease. Tumor research, therefore, also seeks new and more efficient forms of therapy.

Since cytostatics have harmful effect on all cells in the human body, the concept of magnetic drug targeting offers an interesting alternative to conventional tumor therapy [1]. The concept has been described in the literature and tested on animal models. The intravasal availability of the ferrofluids and the magnetic sensitivity were critical. The particles must be large enough to be attracted by a magnetic field, and to migrate into the tumor in this way, in order to release their active substance there [2].

\section{Materials and Methods}

\section{Animal studies}

A magnetic field strength of 0.6 tesla was applied externally to the body [3]. Iron oxides $\left[\mathrm{Fe}_{3} \mathrm{O}_{4}\right]$ were administered intravasally into a vein or artery (Figure 1). Cytostatics were bonded to the iron oxides $\left[\mathrm{Fe}_{3} \mathrm{O}_{4}\right]$. The animal studies were conducted with sarcomas such as rhabdomyosarcoma (Tables 1 and 2).

Results: It was demonstrated that mitoxantrone has a higher concentration in the tumor than the mitoxantrone concentration [2], in the peripheral blood (Table 3).

The results revealed that iron bonded cytostatics contributed towards a reduction in the volume of the tumor and encouraged for further experimental surgical studies (Table 4).

\section{Human study}

70 -year old female patient with metastases mammary carcinoma on left, initial diagnosis in May 2008, has been detected. Further diagnosis was arterial hypertension and obesity $(97 \mathrm{~kg}, 161 \mathrm{~cm})$.

Results: The CT showed an exulcerated timorous mass approx. $10 \mathrm{~cm}$

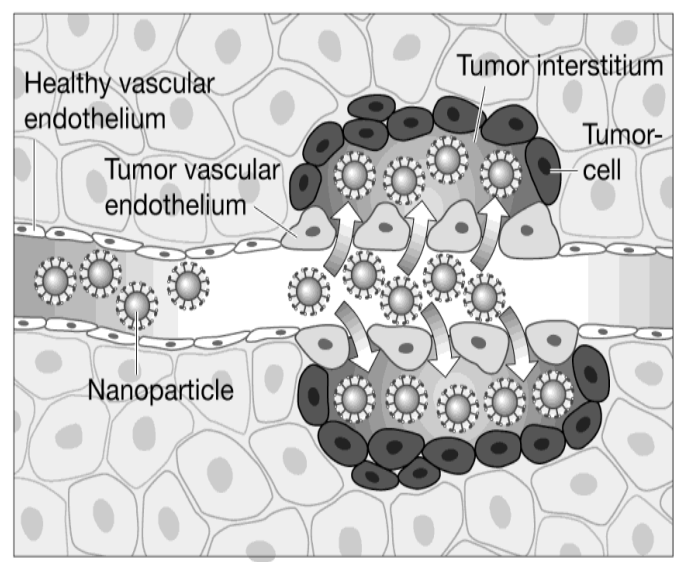

Figure 1: Extravasation of the nanoparticles in the tumor tissue.

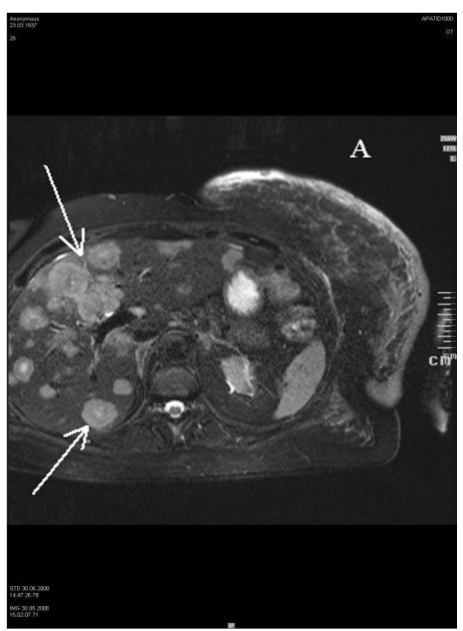

Figure 2: 30.05 .2008 metastasis of liver prior to treatment-arrow marks metastasis in the upper and lower liver, small node as the size of $14.9 \mathrm{~cm}^{3}$.

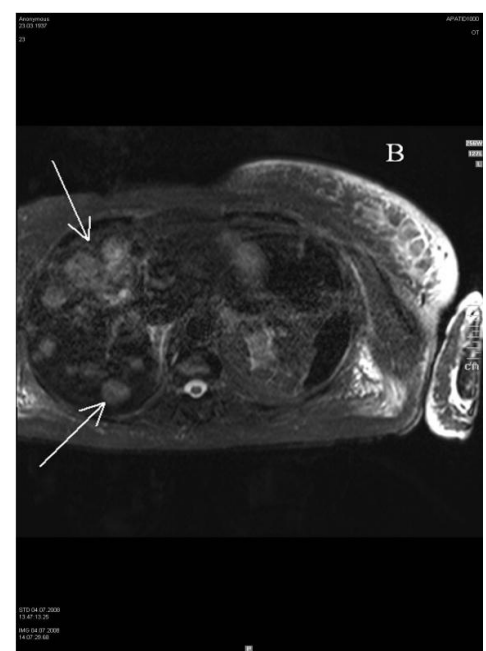

Figure 3: 04.07.2008 four weeks after treatment, reduction of all metastasis in the liver visible-more metastasis in right lobe shrank of $45 \%$ volume, to 8.0 $\mathrm{cm}^{3}$.

*Corresponding author: Krukemeyer MG, Department of Radio-Oncology Paracelsus-Hospital, Sedanstr. 109 D-49076 Osnabrück, Germany, E-mail: drkrukemeyer@t-online.de

Received February 22, 2013; Accepted February 26, 2013; Published February 28,2013

Citation: Krukemeyer MG, Wagner W (2013) Nanomedicine in Cancer Treatment. J Nanomed Nanotechol 4: 166. doi:10.4172/2157-7439.1000166

Copyright: (c) 2013 Krukemeyer MG, et al. This is an open-access article distributed under the terms of the Creative Commons Attribution License, which permits unrestricted use, distribution, and reproduction in any medium, provided the original author and source are credited. 


\begin{tabular}{|c|c|c|c|}
\hline Group & Operative measure & Duration* $^{*}$ & Number of animals \\
\hline I & $\begin{array}{l}1 \mathrm{mg} / \mathrm{kg} \text { BW MagnaDrug mitoxantrone }{ }^{* *} \\
\text { in a magnetic field }\end{array}$ & $\begin{array}{l}\text { Once on one day } \\
30 \mathrm{~min}\end{array}$ & 6 \\
\hline II & $\begin{array}{l}1 \mathrm{mg} / \mathrm{kg} \mathrm{BW} \text { MagnaDrug } \\
\text { mitoxantrone }^{* \star} \quad \text { without a magnet }\end{array}$ & $30 \mathrm{~min}$ & 6 \\
\hline III & $1 \mathrm{mg} / \mathrm{kgBW}$ mitoxantrone ${ }^{\star *} \quad$ without a magnetic field & $30 \mathrm{~min}$ & 6 \\
\hline IV & $\begin{array}{l}1 \mathrm{mg} / \mathrm{kg} \mathrm{BW} \text { MagnaDrug } \\
\text { mitoxantrone }\end{array}$ & $\begin{array}{l}\text { 1st day } 30 \mathrm{~min} \\
2 \text { nd day } 30 \mathrm{~min}\end{array}$ & 6 \\
\hline V & $\begin{array}{l}1 \mathrm{mg} / \mathrm{kg} \mathrm{BW} \text { MagnaDrug } \\
\text { mitoxantrone } \mathrm{e}^{\star *}\end{array}$ & 1st day $30 \mathrm{~min}$ & 6 \\
\hline $\mathrm{VI}$ & $1 \mathrm{mg} / \mathrm{kg}$ BW mitoxantrone ${ }^{* *}$ & 1st day $30 \mathrm{~min}$ & 6 \\
\hline
\end{tabular}

*Duration: Duration of exposure to the magnetic field

** Slow intravenous injection over 5 minutes

Total number $=\Sigma 36$

Table 1: Study groups in the biodistribution.

\begin{tabular}{|c|c|}
\hline Target value & Parameter \\
\hline General condition & survival, reflex status, weight \\
\hline Biodistribution of iron & blood, tumor, liver \\
\hline
\end{tabular}

Table 2: Target values and parameters investigated.

\begin{tabular}{|l|c|c|c|c|}
\hline & Group I & Group II & Group III & Group IV \\
\hline Group I & o/o & o/o & o/o & o/o \\
\hline Group II & 0.6190 & o/o & o/o & o/o \\
\hline Group III & $0.0173^{*}$ & $0.0087^{* *}$ & o/o & o/o \\
\hline Group IV & 0.2403 & 0.2403 & $0.0087^{* *}$ & o/o \\
\hline Group V & 0.0952 & $0.0238^{*}$ & $0.0357^{*}$ & 0.9048 \\
\hline Group VI & 0.1775 & 0.1775 & $0.0079^{* *}$ & 0 \\
\hline
\end{tabular}

* Significant $p$ values

${ }^{* *}$ Highly significant $p$ values

Table 3: $p$ values for comparison of the mitoxantrone concentration in the tumor between Groups I - VI.

\begin{tabular}{|l|c|c|c|c|c|c|c|c|}
\hline Patient L.K. & Unit & Day -2 & Day 0 & Day 1 & Day 2 & Day 3 & Day 4 & After 2 weeks \\
\hline Iron & $\mu \mathrm{gg} / \mathrm{dl}$ & 131 & 44 & 46 & 96 & 117 & 151 & 119 \\
\hline Ferritin & $\mathrm{ng} / \mathrm{ml}$ & 185.7 & 305.1 & 366.8 & 535.4 & 729.5 & 1011.0 & 1985.0 \\
\hline
\end{tabular}

Table 4: Iron oxide and ferritin on day $-2,0,1,2,3$ and 4 and after 2 weeks.

\begin{tabular}{|l|c|c|c|}
\hline Sample designation & & Sample 1 & Sample 2 \\
\hline Matrix & & blood & tumor tissue directly under the magnet \\
\hline Parameter & unit & content & content \\
\hline Microwave pressure break-down $\mathrm{HNO}_{3} / \mathrm{H}_{2} \mathrm{O}_{2}$ & & $\mathrm{X}$ & $\mathrm{X}$ \\
\hline Iron, tot. (Fe) & $\mu \mathrm{g} / \mathrm{dl}$ & 151 & 440 \\
\hline
\end{tabular}

Table 5: Blood sampling on the 4th day.

in diameter in the region of the left breast $(500 \mathrm{ml})$, Table 5 shows the pathologically changed axillary lymph nodes of maximum $2.5 \mathrm{~cm}$ diameter and multiple metastases of maximum $5 \mathrm{~cm}$ diameter, in both lobes of the liver (Figure 2).

The volume of the smaller liver metastasis, identified with an arrow in the right lobe, has decreased from approx. $14.9 \mathrm{~cm}^{3}$ to approx. 8.0 $\mathrm{cm}^{3}$, i.e. by approx. $45 \%$ and until 25.03 .2009 to $90 \%$ (Figure 3).

The exulceration at the breast stopped, so that an imputation of the breast had been successfully performed in 11/2008. The patient has responded well to the therapy. Her physical and mental condition is good and well tolerated, she felt well, and no complications or side effects occurred in the patient.

\section{Conclusion}

The animal study shows in the living organism, an effect of the magnetic field, concentrating on the iron particles. The case study on a human shows a reversible granulocytopenia, neither gastritis, nor alopecia or stomatitis. The data show partial metastatic reduction as per literature. Further patients were treated with the same dose; longterm results are being investigated. This therapy method is a possible option with relatively few side effects.

\section{References}

1. Krukemeyer MG, Wagner W, Jakobs M, Krenn V (2009) Tumor regression by means of magnetic drug targeting. Nanomedicine (Lond) 4: 875-882.

2. Krukemeyer MG, Krenn V, Jakobs M, Wagner W (2012) Mitoxantrone-iron oxide biodistribution in blood, tumor, spleen, and liver--magnetic nanoparticles in cancer treatment. J Surg Res 175: 35-43.

3. Krukemeyer MG, Krenn V, Jakobs M, Wagner W (2012) Magnetic drug targeting in a rhabdomyosarcoma rat model using magnetite-dextran composite nanoparticle-bound mitoxantrone and 0.6 tesla extracorporeal magnetssarcoma treatment in progress. J Drug Target 20: 185-193. 